Ireneusz Milewski (Gdańsk)

\title{
Textile Prices in Early Byzantine Hagiographic Texts. Three Case Studies*
}

\section{Introduction}

$\mathrm{E}$ arly Byzantine hagiographic texts do not offer much information about prices and wages, and what is provided leaves much to be desired. Despite this, such data is cited in studies on the society and economy of late Antiquity. What is distinctive - and, at the same time, confirms the need for research on a specific group of sources (papyrology, patrology) - is that knowing the source specificity (and I mean, above all, various types of cognitive limitations), a number of mistakes can be avoided. This applies primarily to the figures given in literary texts created in the Greek cultural circle. In many, if not most, cases, they cannot be taken literally, and an analysis of but one source confirms that the described events are characterized by the use of repetitive figures reporting prices, wages, tax obligations, time intervals, distances or the number of participants in a given event as well as the number of troops (army size or losses suffered in a battle or war). Historians, especially papyrologists, who are unfamiliar with the nature of Greek Old Christian texts (including early Byzantine hagiographic texts) but are "accustomed" to specific and usually reliable data from the source material they know, tend to cite this information uncritically and even literally. This leads to an attempt to match it with other, more reliable accounts. Unfortunately, these attempts are not justified. I hope that the following reflections will confirm the legitimacy of my doubts. Having conducted a query of early Byzantine hagiographic texts, I would like to draw the reader's attention to just a few examples regarding clothing prices in this source group. Essentially, this is the only information on this subject that I was able to find in the hagiographic texts written in the Roman East from the mid $-4^{\text {th }}$ to the mid $-7^{\text {th }}$ centuries. Let us now examine specific examples.

\footnotetext{
* This article was written with the financial support of Poland's National Science Centre (UMO2015/17/B/HS3/00135).
} 


\section{Vita Melaniae Iunioris. How much is/should an ascetic's robe be worth?}

Vita Melaniae Iunioris, written by Gerontius of Jerusalem, is one of the most interesting early Byzantine hagiographic texts. It provides a lot of valuable information about the Empire in the first decades of the $5^{\text {th }}$ century. Among the abundant data highlighting the social and economic situation at the time, it contains information about prices, including the alleged price of Pinian's i fá $\tau$ เov. Pinian, the spouse of Melania the Younger, similarly to his wife, was a member of the ancient Roman Valeria family ${ }^{1}$. In subsequent years, together with Melania, he gaveaway his wealth. Pinian's new life path was symbolized by donning a new robe - the ascetic robe, íá́tıov. According to Gerontius, it "was worth less than one solidus"

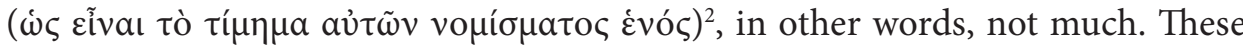

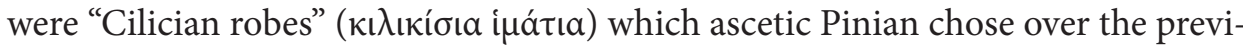

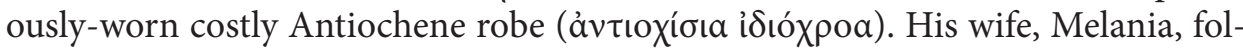
lowed his example, but in her case, the price of the new robe was not given ${ }^{3}$. That is all the information on the prices of clothes of spouses provided in Vita graeca. A different value of this robe in indicated in Vita latina. According to this account, it cost tabulas quinque, hence, five siliquae, which is slightly more than two-thirds of a solidus ${ }^{4}$. Federico Morelli tries to analyze this information by searching for similar prices for a tunic in other early Byzantine sources. For this purpose, $\mathrm{He}$ turns to Tabulae albertini and data from papyri ${ }^{5}$. His efforts, however, do not bring any tangible result, except for the conclusion that the price given by Gerontius deviates significantly from the value of analogous tunics relayed in other sources. Morelli's research did not produce constructive findings because it was futile. In this case, Gerontius' account was completely undeserving of attention as it is unreliable. By stating that the robe purchased by Pinian was worth less than one solidus, Melania's biographer wants to communicate that its value was negligible. The same method of determining the value of clothing or other goods (or services) is characteristic of all late Antiquity Christian Greek literature, including the hagiographic texts created at that time (comments on this subject below). Nonetheless, even in this case, there is a difference; in these texts, when a pauper or a beggar is referenced, the value of their clothing is defined as "one", "three" or a maximum of "several obols", in other words, that it was not worth much. Such a comparison, however, could not be applied to the aristocrat, Pinian, which is why the account mentions "a piece of gold", rather than one or several obols. A repetitive use of

\footnotetext{
${ }^{1}$ On Melania the Younger see A.H.M. Jones, J.R. Martindale, J. Morris, Prosopography of the Later Roman Empire, Cambridge 1971, p. 593 (s.v. Melania 2).

${ }^{2}$ Vie de sainte Mélanie, 8, trans. et ed. D. Gorce, Paris 1962 [= SC, 90] (cetera: Gerontius). Cf. also F. Morelli, Tessuti e indumenti nel contesto economico tardoantico: I prezzi, ATa 12, 2004, p. 74.

${ }^{3}$ Gerontius, 8. Cf. also F. Morelli, Tessuti e indumenti..., p. 74, n. 110.

${ }^{4}$ Gérontius, La Vie Latine de Sainte Mélanie, 8, trans. et ed. P. Laurence, Jerusalem 2002 [= SBF. CM, 41]: tabulae cinquae = 5 siliquae; cf. F. Moreldi, Tessuti e indumenti..., p. 74 (n. 111), 75.

${ }^{5}$ F. Morelli, Tessuti e indumenti..., p. 74-75.
} 
values - such as those cited above, regardless of circumstances - is one of the multiple cognitive deficiencies of ancient Christian literature created in the Greek cultural circle. More examples supporting the validity of this statement will be given in the critical remarks to the analyzed main accounts.

\section{Pratum spirituale. Clothing prices in the collection of "uplifting stories"}

Another interesting data can be found in Pratum spirituale (The Spiritual Meadow) by John Moschos (540/50-620). It is a valuable source on the history of early Byzantine monasticism, especially Palestinian. Similarly to the Egyptian Apophthegmata Patrum, it is a collection of instructive, and, above all, "uplifting", stories from the lives of more or less known monks as well as fictional characters. Probably, not all of these stories were written by John Moschos. For the purpose of his work, he also adopted the accounts of other authors circulating in the monastic environment ${ }^{6}$.

Reflecting the atmosphere of early Byzantine monasticism, Pratum spirituale also provides insight, if somewhat imperfect, into the social and economic situations of that period. Occasionally, this collection of "uplifting stories" also touches on the issue of money, including costs and clothing prices. The accounts, in which we are interested here, are stories "with a moral", which are skewed by nature, and for this reason alone, should be approached rather carefully. In the first case, a monk gets wrongly accused of stealing a solidus. The story begins when one of the protagonists, abba Andrew of Messenia, a young friar at the time, accompanies his abbot to Palestine, probably to Jerusalem. They stay there in $\xi \varepsilon v o \delta o x \varepsilon \tilde{c}$, sharing the room with an old man, also a monk. The old man has a piece of gold ( $v$ ó $\mu \digamma \mu \alpha \tilde{\varepsilon} v$ ), which he hides in fear of other guests from the inn. Suffering from dementia, the old man forgets about the secret place and accuses monk Andrew of stealing his money. Although he is not guilty, he decides to sell his cloak ( $\pi \alpha \lambda \lambda i ́ o v)$ "for one piece of gold" ( $v$ ó $\mu \sigma \mu \alpha)$, which was exactly the amount he was accused of stealing. Naturally, the coat is worth more, but monk Andrew deliberately sells it at no profit. One of the many topoi of early Byzantine hagiographic literature is of monks selling various goods, including their handiwork, at no profit and without haggling with the buyer. Let us return to the story told by John Moschos. The protagonist of the story unfairly accused of theft accepts the blame, claiming that he was misguided by Satan, and tries to give the old man the solidus obtained from the sale of his cloak. However, the

${ }^{6}$ H. Chadwick, John Moschus and His Friend Sophronius the Sophist, JTS 25, 1974, p. 41sqq; P. PatTENDEn, The Text of the Pratum Spirituale, JTS 26, 1975, p. 38-54; E. Follieri, Dove e quando mori Giovanni Mosco?, RSBN 25, 1988, p. 3-39; B. Flusin, Palestinian Hagiography (Fourth-Eight Centuries), [in:] The Ashgate Research Companion to Byzantine Hagiography, vol. I, Periods and Places, ed. S. Efthymiadis, Farnham-Burlington 2011, p. 199sqq; B.L. Ihssen, John Moschos' Spiritual Meadow. Authority and Autonomy at the End of the Antique World, Washington 2013, p. 1-19. 
old man refuses to accept it, because in the meantime, he found the hidden piece of gold and asks the young monk to forgive him for the unjust accusation. Since it was supposed to be a moral story, the sclerotic old man is greatly encouraged by the fact that although the young monk did not steal his solidus, he took the blame to relieve the old monk's misery?

Another story included in Pratum spirituale is equally didactic, so as not to say "uplifting". However, it should also be disregarded in research on the level of prices at the turn of the $6^{\text {th }}$ and $7^{\text {th }}$ centuries. This text presents the realities of Italy under Gregory the Great. John Moschos recounts the story of Peter, a priest of the Roman Church, who describes the establishment of one of the monasteries founded by Pope Gregory. The monks gathered in it were forbidden from owning

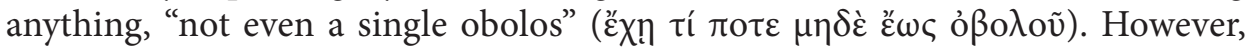

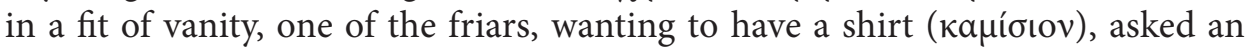
outsider to buy him a new one. The person asked for a favor, his brother who was "living in the world", does not make the purchase, but offers the friar "three pieces

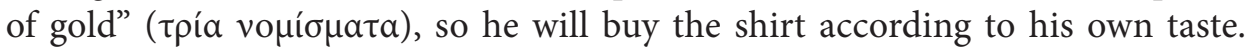
At this point in the narrative, the convention of an "uplifting" story requires a plot twist. And then, the monk took the three pieces of gold, and went and reported it to his higoumen, who, when he heard it, went and reported it to the most holy pope, to the bishop of Rome, Gregory. As a consequence, the friar gets excommunicated for acting against the rules. The excluded monk, anguished by this fact, dies ${ }^{8}$.

\section{Vita Joannis Eleemosynarii. The gonachion's price in Alexandria in the first half of the $7^{\text {th }}$ century}

Leontius, the Bishop of Cypriot Neapolis (590-668), left behind a valuable source for learning about the social and economic realities of early Byzantine Egypt, and in particular of Alexandria in the early $7^{\text {th }}$ century. This text is Vita Joannis Eleemosynarii, which was most probably written in 641-6429. John the Almsgiver, the hero of his main work, was patriarch of Alexandria (610-620), an ecclesiastical leader of Egyptian Church, and "a model of charitable activity"

\footnotetext{
${ }^{7}$ Joannes Moschus, Pratum spirituale, 116, [in:] PG, vol. LXXXVII.3 (cetera: JoAnnes Moschus). Cf. also F. Morelli, Tessuti e indumenti..., p. 70.

${ }^{8}$ Johnnes Moschus, 192 (trans.: John Moschos, The Spiritual Meadow, ed. et trans. J. Wortley, Kalamazoo 1992, p. 165). Cf. also F. Morelli, Tessuti e indumenti..., p. 75, n. 119.

${ }^{9}$ E. Dawes, N.H. Baynes, Three Byzantine Saints. Contemporary Biographies Translated from Greek, Oxford 1948, p. 195-198; C.A. MANGO, A Byzantine Hagiographer at Work: Leontion of Neapolis, [in:] Byzanz und der Westen. Studien zur Kunst des europäischen Mittelalters, ed. I. HutTer, Wien 1984, p. 33; V. DÉroche, Études sur Léontios de Néapolis, Upsala 1995 [= SBU, 3], p. 25-36; S. EFTHYmiadis, V. Déroche, A. Binggeli, Z. Aïnalis, Greek Hagiography in Late Antiquity (Fourth-Seventh Centuries), [in:] The Ashgate Research Companion..., p. 72-73.

${ }^{10}$ S. Efthymiadis, V. Déroche, A. Binggeli, Z. Aïnalis, Greek Hagiography..., p. 73.
} 
Stories included in early Byzantine hagiographic texts typically feature a pauper and a rich man - a Christian, who comes to his aid. Sometimes, as shown in the example of the Alexandrian priest Isidore, it is necessary to resort to trickery to cajole an affluent woman to share her wealth with the poor ${ }^{11}$. Other times, compassion for an impoverished fellowman comes on its own, spurred by the lifestyle of the beneficiary, in this case, widely-respected John, Patriarch of Alexandria, the title protagonist of Leontius' work. Vita Joannis Eleemosynarii recounts the story of purchasing a jovaxíwv for the Alexandrian patriarch. This is where the narrative first raises questions. We are unable to unequivocally state what the term defines. The term " yovaxí $\omega v$ " has multiple meanings. It can mean: a blanket, a cloak or maybe a cape, which you could either cover your back when going out or use as a cover during sleep. The description of the circumstances of the event suggests that it might be the latter: a type of throw that could serve both as an outer garment and as a blanket under which you could sleep ${ }^{12}$. Either way, this doubt is not central to the analyzed account. When one of the affluent and pious Christians from Alexandria sees the conditions in which the patriarch sleeps, he decides to buy him a new comfortable bed and the aforementioned yovaxíwv

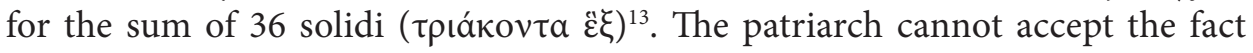
that from now on, he will sleep "in luxuries" while the local poor, the "brothers of Christ", are lying on the streets and dying from cold. The convention of a hagiographic work requires taking action. The patriarch decides to sell the jovaxí $\omega v$. A man sent to the market for this purpose is noticed by the donor, who first made that purchase. He decides to buy back the jovaxíwv for the same amount he paid earlier, 36 solidi, and then orders its delivery back to the patriarch's house. Bishop John, not discouraged by this, sends his servant back to the market the next day to try to sell, what he claims to be, an "unessential thing" for him. This continues for two consecutive days, and as a result, the patriarch "sells" the gifted cloak three times, collecting over 100 pieces of gold. For the money obtained from the thricesold gonnachion, John purchased 144 cloaks of inferior quality for the Alexandrian poor ${ }^{14}$.

\footnotetext{
${ }^{11}$ Palladius, The Lausiac History, 6, 8-20, vol. II, ed. et trans. C. Butler, Cambridge 1904 (cetera: Palladius, Historia Lausiaca).

${ }^{12}$ F. Morelli, Gonachia e kaunakai nei papiri con due documenti inediti (P.Vindob. G 1620 e P.Vindob. G 18884) e uno riedito (P.Brook. 25), JJP 32, 2004, p. 55sqq; W. Clarysse, Clothing the House. Furnishing Textiles of the $1^{\text {st }}$ Millennium AD from Egypt and Neighbouring Countries, [in:] Textiles and Architecture in the Graeco-Roman and Byzantine Egypt. Proceedings of the $5^{\text {th }}$ Conference of the Research Group 'Textiles from the Nile Valley', 6.10.2007-7.10.2007, ed. W. Clarysse, K. GeEns, A. De Moor, C. Fluck, Antwerp 2009, p. 39-40.

${ }^{13}$ Leontius Neapoleos, Vita Joannis Eleemosynarii, 21, [in:] Leontios von Neapolis Leben des hl. Johannes des Barmherzigen, ed. H. Gelzer, Freiburg im Breisgau 1893 (cetera: Leontius Neapoleos, Vita Joannis Eleemosynarii). Cf. F. Morelli, Tessuti e indumenti..., p. 55-56, 69-71.

${ }^{14}$ Cf. G. Ostrogorsky, Löhne und Preise in Byzanz, BZ 32, 1932, p. 326.
} 
This is what we can glean from this story: the alleged circumstances, in which the patriarch tries to sell the blankets gifted him, and the considerable sum he effectively raises to continue supporting the local poor. One could say: one of many "pious" stories, in which early Byzantine hagiography abounds. In his text on the prices of textiles, Federico Morelli tries to match the price of the blanket to other source data, primarily to the data from papyri. Italian scholar assumes that the right method to determine the cognitive value of information about the price of the gonachion mentioned in Vita is to compare it with other values provided in the text, especially the wages. Hence, according to the author, to collect money for the coat, you would have to work for 18 years in Alexandria, for a monthly salary (?) which John earned, i.e. for $1 / 3$ or $1 / 6$ solidus. Based on the papyrus documents from the $6^{\text {th }}$ century, Morelli estimated that 36 solidi, the sum for which the povaxí $\omega v$ was allegedly purchased, would have bought food for a family of four for at least 10 years, assuming that wheat was a staple in their diet. Once again, Morelli's efforts are quite baffling, because the author attempts to collate incomparable values. Rather succinct information on the price of the cloak cannot be referred to the prices of this type of goods given in other sources, which are cognitively more valuable. Any attempts in this regard remain questionable as blankets vary in terms of their size or quality of the material from which they were sewn.

\section{Critical remarks}

The examples discussed above confirm the validity of the statement that Christian texts created in the Greek cultural circle typically provide repetitive data on salaries, prices or other sums of money. The cited cases illustrate the reality of everyday life in Palestine (from the 420/430s to the middle of the $6^{\text {th }}$ century), Egypt (Alexandria of the beginning of the $7^{\text {th }}$ century) and Italy (the turn of the $6^{\text {th }}$ and $7^{\text {th }}$ centuries, the times of Gregory the Great). Admittedly, both the territorial and chronological dispersion of this data is considerable, but this aspect is not the most important in this case. The compiled data exhibits two common features: the fact that it was recorded in hagiographic texts created from the mid- $5^{\text {th }}$ to the mid $-7^{\text {th }}$ centuries, and the fact that, regardless of the circumstances in the analyzed texts, the same, repetitive figures appear.

The validity of the above remark, articulated belief that the compiled data are unreliable, is also confirmed by other numerical data that we find in the analyzed texts. In Vita Joannis Eleemosynarii we read, when John Almsgiver learnt, that the church of Jerusalem is in great distress he sent him towards the rebulding and repairing of the churches 1000 numismata, 1000 sacks of corn, and 1000 of pulse, $1000 \mathrm{lb}$ [pounds - IM] of iron, 1000 casks of dried fish called "Maenomene", 1000 jars of wine and 1000 Egyptian wormen ${ }^{15}$. Any comment on the account above

\footnotetext{
${ }^{15}$ Leontius Neapoleos, Vita Joannis Eleemosynarii, 20 (trans.: E. Dawes, N.H. Baynes, Three Byzantine Saints..., p. 229).
} 
seems redundant. Similar repeatable data we also find in Pratum spirituale: "3 gold denarii", as an alm given to the poor ${ }^{16}$, or " 3 gold pieces" as a payment for document to chancellor ${ }^{17}$. Many analogous data from the texts analyzed above could be given. This, however, is already material for separate study.

Let us return to the main thread of our considerations. Of course, we can compare the above discussed data with the prices of clothing that are found in other late Roman and in early Byzantine texts, starting from the information on the subject traced in Edictum de pretiis rerum venalium or in Tabulae albertini and finishing with papyrus data from Egypt in Byzantine and early Arab period. As the findings of Federico Morelli's extensive study on the prices of textiles in late Antiquity show, the cognitive effect, based on hagiographic texts, is really doubt$\mathrm{ful}^{18}$. Unfortunately, the data compiled above does not reflect the actual prices of textiles in the analyzed period (from mid- $5^{\text {th }}$ to mid- $7^{\text {th }}$ centuries) and should be considered valueless. The same applies to the information found on prices, wages or taxes in all late Christian Greek literature. These texts employ repetitive data, characterized by the use of identical digits (one, three, seven) and numerals $(10,30,100,300,1,000$, etc.). So as not to make idle claims, let us cite specific examples. In early Byzantine hagiographic texts, slave prices ranged from three

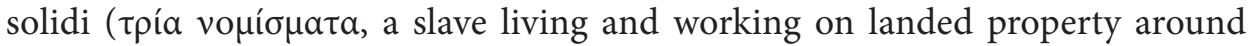

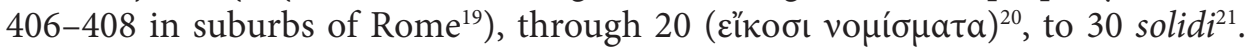
While in the first quotation, the amount is low, the price of 30 solidi for a slave is considerable (however, due to a "certain value" of a slave, the author of the account could not phrase it as "severals obols", the way it is done in the case of a poor man's clothing prices). Apophthegmata patrum mentions the price of flax equal to 1 gold piece ( $\check{\varepsilon} v \chi \rho v ́ \sigma ı v o v / v o ́ \mu t \sigma \mu \alpha)^{22}$. According to John Moschos, a copy of the New Testament "written on extremely fine skins" in Palestine in the mid- $6^{\text {th }}$ century cost three pieces of gold ${ }^{23}$, hence, not very much, which is probably untrue. In that period, the prices for calligrapher services were quite significant.

\footnotetext{
${ }^{16}$ JoAnnes Moschus, 195.

${ }^{17}$ JoAnnes Moschus, 193.

${ }^{18}$ F. Morelli, Tessuti e indumenti..., p. 57sqq, 73sqq. On the manner of repeating identical numbers and numbers in literary texts cf. also E. TAVEnNer, Three as a Magic Number in Latin Literature, TPAPA 47, 1916, p. 117-143; P. Devos, Les nombres dans l'Historia monachorum in Aegypto, AB 92, 1974, p. 97-108; R. Mehrlein, Drei, [in:] Reallexikon für Antike und Christentum, vol. IV, ed. T. KLAuser, Stuttgart 1959, col. 269-310.

${ }^{19}$ Palladius, Historia Lausiaca, 61.

${ }^{20}$ Palladius, Historia Lausiaca, 37, 2-4. However, the story described on this occasion devalues the cognitive value of this information.

${ }^{21}$ Cf. G. Ostrogorsky, Löhne..., p. 300.

${ }^{22}$ Apophthegmata patrum. Collectio alphabetica, 417 (Joannes Persicus 2), [in:] PG, vol. LXV (cetera: Apophthegmata patrum. Collectio alphabetica). Cf. also I. Milewski, Money in the Apophthegmata Patrum, SCer 9, 2019, p. 608-609.

${ }^{23}$ JoAnnes Moschus, 134.
} 
A similar situation applies to earnings. Early Byzantine hagiographic texts

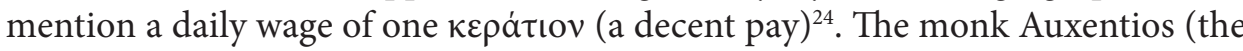
$5^{\text {th }}$ century) provides another example. If one believes the assurances of his biographer, Auxentios worked in a Constantinopolitan workshop doing unspecified

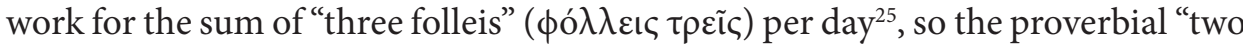
cents", which is not much. In early Byzantine texts the prostitute earns an income

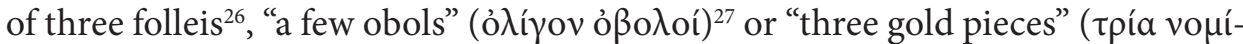
$\sigma \mu \alpha \tau \alpha)^{28}$. On the other hand, a text depicting the realities of the Edessa (Upper Mesopotamia) in the mid- $7^{\text {th }}$ century, i.e., notes that the monk Paul, working as an "unskilled craftsman", earned 100 folleis a day ${ }^{29}$. The same texts mention dona-

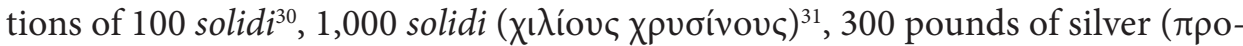

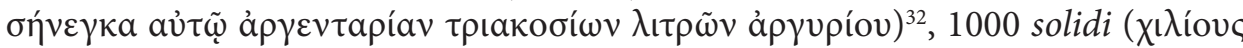

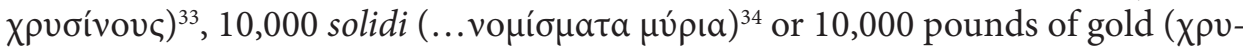

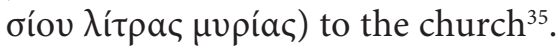

${ }^{24}$ Leontius Neapoleos, Vita Joannis Eleemosynarii, 36 (monk Vitalis); Vita Danielis, [in:] Vie et recits de Abbe Daniel de Scêtê, ed. L. Clugnet, ROC 5, 1900 (cetera: Vita Danielis), p. 266 (monk Eu-

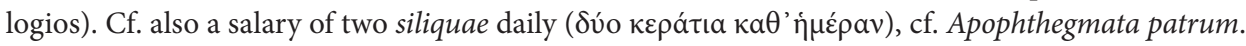
Collectio alphabetica, 763 (Pambo 2).

${ }^{25}$ Vita s. Auxentii, 1, 7, [in:] PG, vol. CXIX.

${ }^{26}$ Procopius, Historia arcana, 17, 5, [in:] Procopius with an English Translation, vol. VI, The Anecdota or Secret History, ed. H.B. Dewing, Cambridge Mass. 1960 (cetera: Procopius, Historia arcana).

${ }^{27}$ Procopius, Historia arcana, 25, 12.

${ }^{28}$ Palladius, Historia Lausiaca, 65, 2. Cf. also I. Milewski, "Take her, and pay me three gold pieces a day as her hire". Palladius of Helenopolis on Income from Lenocinium, [in:] Byzantina et Slavica. Studies in Honour of Professor Maciej Salamon, ed. S. Turlej, M. Stachura, B.J. KoŁoczeK, A. IzDEBSKI, Kraków 2019 p. 275.

${ }^{29}$ Cf. G. Ostrogorsky, Löhne..., p. 298.

${ }^{30}$ Cyrillus Scythopolitanus, Vitae Monachorum Palestinensae (Vita Theodosii, 3), [in:] E. Schwartz, Kyrillos von Skythopolis, Leipzig 1939 [= TUGAL, 49.2] (cetera: Cyrillus Scythopolitanus).

${ }^{31}$ Palladius, Dialogue sur la vie de Jean Chrysostome, 6, 58, vol. I-II, ed. et trans. A.M. Malingrey, P. Leclerce, Paris 1988 [= SC, 341-342] (cetera: Palladius, Dialogus); Cyrillus ScythopolitaNus (Vita Sabae, 72-73).

${ }^{32}$ Palladius, Historia Lausiaca, 10.

${ }^{33}$ Palladius, Dialogus, 6, 58.

${ }^{34}$ Palladius, Historia Lausiaca, 61.

${ }^{35}$ Vita Olympiadis, V, 21-33; VII, 3-4, ed. et trans. A.-M. Malingrey, Paris 1968 [= SC, 13 bis]. Author of Vita listed also another donation, namely 20,000 pounds of silver to the Constantinopolitan

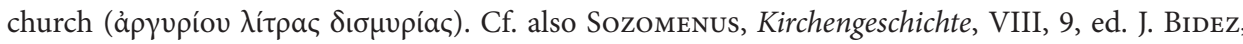
G.C. Hansen, Berlin 1995 [= GCS.NF, 4] (cetera: Sozomenus) and G. Dagron, Naissance d'une capitale. Constantinople et ses institutions de 330 à 451, Paris 1974 [= BBE, 7], p. 501-506. 
Identical digits and numerals, as in the case of prices, wages or donations, are also used in determining the amount of $\mathrm{alms}^{36}$, $\operatorname{taxes}^{37}$, fines ${ }^{38}$, size of property ${ }^{39}$, distances ${ }^{40}$, time periods ${ }^{41}$ or the number of people participating in the described event $^{42}$, ransom ${ }^{43}$ or bribe ${ }^{44}$. When the authors of hagiographic texts quote the number of widows ${ }^{45}$, monks ${ }^{46}$, a small amount of money ${ }^{47}$, as well as the other values $^{48}$, they are numbered in a similar fashion, they usually give the following numbers: $10,30,100,300,1,000,3,000$ or 10,000 . The data confirming the legitimacy of my observations given in footnotes are of course selective. It is not possible to list them all.

\footnotetext{
${ }^{36}$ Alms: Gerontius, 51; Vita Danielis, p. 60 (alms in the amount to 100 folleis per day).

${ }^{37}$ Taxes: Basilius Magnus, Epistula, 40, [in:] PG, vol. XXXII (the alleged tax of 1000 pounds to pay for the costs of the Persian expedition of Emperor Julian in 363). Cf. also THÉOdORET DE CYR, Histoire des moines de Syrie, 17, 3, vol. I-II, ed. et trans. P. Canivet, A. Leroy-Molinghen, Paris 1977-1979

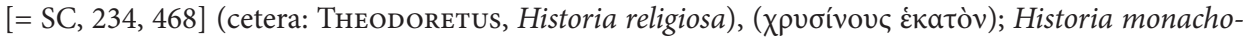
rum in Aegypto, 14, 5-8, ed. A.-J. Festugiere, Bruxelles 1971 [= SHa, 53] (cetera: Historia monachorum in Aegypto) ( tolorum, 11, 3, [in:] PG, vol. LX (estimated tax of 10000 gold pieces). Cf. also J. KaraYAnnopulos, Das Finanzwesen des frühbyzantinischen Staates, München 1958, p. 129, 143.

${ }^{38}$ Sozomenus, V, 4 (the alleged fine for the destruction of the pagan temple in Cappadocian Caesarea).

${ }^{39}$ Basilius Magnus, In illud: destruam horrea mea, 3, [in:] PG, vol. XXXI (a fortune worth "thousands of gold pieces"); JoAnnes Chrysostomus, Ad populum Antiochenum, 2, 6, [in:] PG, vol. XLIX (annual income of tens of thousands of gold); Joannes Chrysostomus, In Acta Apostolorum, 11, 3, [in:] PG, vol. LX (the wealth of Constantinople's richest inhabitants is estimated "at 1 million pounds of gold, or two or maybe even three times more"); Jonnnes Chrysostomus, In Epistulam I ad Corinthios, 5, 5, [in:] PG, vol. LXI ("a property" of poor man's worth "one obolos").

${ }^{40}$ Distances: Theodoretus, Historia religiosa, 10, 4; 25, 1.

${ }^{41}$ Time periods: Theodoretus, Historia religiosa, 2, 14, 17; 26, 4-5; 28, 3; Historia monachorum in Aegypto, 1, 12, 64; 14, 6; Apophthegmata patrum. Collectio alphabetica 97 (Agaton 15); 239 (Zenon 5); 417 (Joannes Persicus 2); 486 (Macarius 33); 586 (Pojmen 12); 540 (Mios 2); 535 (Megethios 1); 966 (Nisteroos 6); Cyrillus Scythopolitanus (Vita Euthymii, 37). The same applies to measuring time, in which case the most common statements are: "in a short time", "in a few days", "in a day", "in three days", "on the third day", or "on the third night".

${ }^{42}$ Number of people/inhabitants: Joannes Chrysostomus, In Acta Apostolorum, 11, 3, [in:] PG, vol. LX (100 000, the number of Christians in Constantinople at the turn of the $4^{\text {th }}$ and $5^{\text {th }}$ centuries); Joannes Chrysostomus, In Johannem, 58, 4, [in:] PG, vol. LIX; Historia monachorum in Aegypto 14, 5-8; 17, 5; Theodoretus, Historia religiosa, 12, 6; Apophthegmata patrum. Collectio alphabetica, 789 (Paphnuti 4).

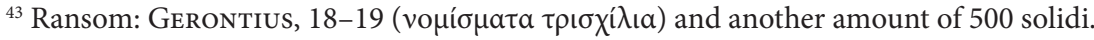

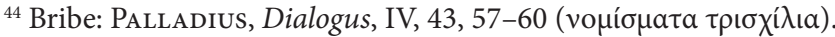

${ }^{45}$ Number of "widows and virgins" in Antioch, cf. Joannes Chrysostomus, In Matthaeum, 66 (67), 3, [in:] PG, vol. LVII-LVIII.

${ }^{46}$ Number of monks: Theodoretus, Historia religiosa, 3, 4; Historia monachorum in Aegypto, 5, 6.

${ }^{47}$ Small amount of money: Palladius, Historia Lausiaca, 58, 2 ( $\tau$ pía vo $\left.\mu i ́ \sigma \mu \alpha \tau \alpha\right)$.

${ }^{48}$ Other values: Joannes Chrysostomus, In Epistulam II ad Timotheum, 3, 3, [in:] PG, vol. LXII (theft of 10 obols); Historia monachorum in Aegypto, 14, 19 (distribution of ten bags of vegetables among the poor); Cyrillus SCythopolitanus (Vita Euthymii, 15) - 30 rooms; Cyrillus ScythoPOLITANus (Vita Sabae, 58) - 30 wine tubes.
} 
The repetitiveness of the data cited above is characteristic of all Ancient Greek literature, from Herodotus ${ }^{49}$ and Thucydides ${ }^{50}$, through the late Antique Greek patristic literature (John Chrysostom ${ }^{51}$ or Gregory of $\mathrm{Nyssa}^{52}$, among others) to the works of Procopius of Caesarea ${ }^{53}$. An identical method of determining numerical data is also characteristic for the literature of middle and late Byzantine period ${ }^{54}$. Interestingly, these features also recur in texts written in Latin, but created in the Greek cultural circle, such as some of the works of John Cassian ${ }^{55}$ and Jerome ${ }^{56}$. In other words, the nature of the quoted data was not determined by the language but by the readers and the methods of determining certain values, quantities and distances, which they used and understood.

${ }^{49}$ Cf. D. Fehling, Die Quellenangaben bei Herodot. Studien zur Erzählkunst Herodots, Berlin-New York 1971 [= ULG, 9], p. 155-167; K. Ruffing, 300, [in:] B. Dunsch, K. Ruffing, Herodots Quellen - die Quellen Herodots, Wiesbaden 2013, p. 201-221.

${ }^{50}$ C. Rubincam, Qualification of Numerals in Thucydides, AJAH 4, 1979, p. 77-95.

${ }^{51}$ According to John Chrysostom, in Antioch at the turn of the 380s and '90s, the medical fees for

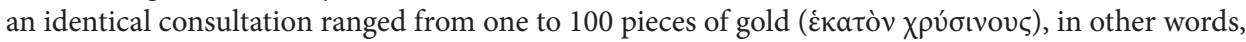
some patients were charged very little and others substantially more, cf. JoANnEs CHRYsostomus, In paraliticum per tectum demissum, 4, [in:] PG, vol. LI and H.J. Frings, Medizin und Arzt bei den griechischen Kirchenvätern bis Chrysostomos, Bonn 1959, p. 91-92; U. BaCHmann, Medizinisches in den Schriften des griechischen Kirchenvater Johannes Chrysostomos [PhD Thesis, Düsseldorf 1984], p. 99. Cf. also JoAnnes Chrysostomus, In Epistulam ad Ephesios, 21, 3, [in:] PG, vol. LXII (philosophers worth 3 obols, so nothing); JoAnnes Chrysostomus, In Epistulam ad Philippenses, 10, 3, [in:] PG, vol. LXII: hundreds of solidi for dresses paid by wealthy Antiochian women, and at the same time a poor man can afford to buy clothes for just 1 silver piece. Cf. also A. GonZALEZ-BLANCO, Economia y sociedad en el Bajo Imperio segun san Juan Crisostomo, Madrid 1980, p. 160; I. MiLEWSKI, Löhne und Preise bei den Kappadokischen Kirchenvätern und bei Johannes Chrysostomus, MBAH 19.1, 2000, p. 51-52.

${ }^{52}$ Cf. Gregory of Nyssa account (Gregorius Nyssenus, Epistulae, 25, 12, ed. P. Maraval, Paris 1990 [= SC, 363]) about masons recruited to build the church in Nyssa. The bishop hired 30 craftsmen for "one piece of gold per day". Meanwhile, in Contra usurarios, [in:] PG, vol. XLVI, col. 449, the same author states that one of the local loan sharks, a wealthy man, was so stingy that he could not bare to spend "three obols" on an entry to the public bathhouse in Nyssa, namely, pay a very small fee. Cf. also R. TEjA, Organizacion economica y social de Capadocia en el siglo IV, segun los Padres Capadocios, Salamanca 1974, p. 161.

${ }^{53}$ Including the sums, which Procopius quoted for the ransom paid by the early Byzantine cities to the Persian invaders, cf. I. MiLewski, Lýtron. Okup za odstapienie od oblężenia miasta jako element strategii wojennej Chosroesa I w De bello Persico Prokopiusza z Cezarei, SDŚ 23, 2019, p. 143-170. Cf. also C. Whately, Some Observations on Procopius' Use of Numbers in Descriptions of Combat in Wars Books 1-7, Phoe 69, 2015, p. 395-396.

${ }^{54}$ Cf. G. Ostrogorsky, Löhne..., p. 293-333.

${ }^{55}$ I. Milewski, Panis et vinum. Einige Bemerkungen zu den Lebensmittelpreisen und Ernährungsgewohnheiten des spätantiken Menschen bei den griechischen und lateinischen Kirchenväter, [in:] W kregu antycznych politei. Księga Jubileuszowa ofiarowana Profesorowi Janowi Ilukowi, ed. W. GaJewski, I. Milewski, Gdańsk 2017, p. 265.

${ }^{56}$ I. Milewski, Winnica eremity Saby. Uwagi na temat Vita Hilarionis 17, 26-27 autorstwa Hieronima ze Strydonu, SGd 42, 2018, p. 82-84. 
What is equally interesting, a quotation of repetitive digits and numerals for specifying prices is also visible in papyrus texts, in private correspondence. Essentially, it is rather obvious, since this was the way contemporaries defined certain values. This statement is supported by an anonymous letter, dated to the $5^{\text {th }}$ century, sent to an equally anonymous addressee (in many cases, due to the succinct nature of the text and its fragmentary preservation, it is impossible to determine its author, addressee or the exact time of writing the letter). The author of the letter informs his addressee that, having no money for daily subsistence, he just sold one of his coats for " 10 artabas of wheat" (circa 300 kilograms). This information was used by Morelli to calculate the value of the cloak sold, or in fact, exchanged for cereal. Bearing in mind the average price of wheat in Egypt in the $5^{\text {th }}$ century, the author came to the simple conclusion that the cloak cost "one solidus" ${ }^{57}$. Of course, it cannot be ruled out that in the $5^{\text {th }}$ century Egypt, it was possible to buy a gonnachion for as little as one piece of gold, but I believe that trusting the above-quoted account is too hasty, so as not to say naive. If we were to apply the method of treating numerical data literally (in this case, prices), we might revert to the accounts of Julian the Apostate ${ }^{58}$ and John Chrysostom ${ }^{59}$, who mention the price of grain in Antioch at one piece of gold per one or ten artabas. However, these accounts are also not credible.

Let us return to the prices of clothing we have discussed earlier. The fact that the reported data cannot be treated literally is one issue, and another is why the same numbers are given in a repetitive fashion. Does their topicality equal saying that in the reported cases, the "right" price was paid; that a tunic or a cloak cost what they should have? Perhaps the explanation should be sought in the fact that the authors of the discussed accounts did not know the actual price of the goods and provided their topical value, which was of secondary importance to the character and moral of the story. Let us consider the obvious fact that the contemporaries knew the level of prices at the time, so the reader of a hagiographic work was able to determine their validity. Simply put, providing an abnormally low or inflated price, in this case, could additionally depreciate the truthfulness and strength of the account recorded in the hagiographic text. Therefore, from the point of view of the author of a hagiographic work, statements about certain sizes, values or distances were made without attention to detail, yet such a way of specifying them was understandable to the readers at the time. However, there

\footnotetext{
${ }^{57}$ F. Morelli, Tessuti e indumenti..., p. 69-70.

${ }^{58}$ Julien, Le Misopogon, 41, [in:] L'Empereur Julien, Ouvres complètes, vol. II, ed. C. Lacombrade, Paris 1964 [= CUF] (one gold piece for 10 artabas of grain). Cf. also C. Morrison, Monnaie et prix à Byzance du V au VII s., [in:] Hommes et richesses dans l'Empire byzantine, IV-VII s., ed. P. LeTHIELLEUX, Paris 1989, p. 257.

${ }^{59}$ Johnnes Chrysostomus, In Epistulam I ad Corinthios, 39, 8, [in:] PG, vol. LXI (one gold piece for 1 artaba of grain).
} 
is no doubt that this data cannot be treated literally, as the papyrologist and historian Federico Morelli does in his otherwise engrossing and very useful detailed study.

Translated by Katarzyna Szuster-Tardi

\section{Bibliography}

\section{Primary Sources}

Apophthegmata Patrum. Collectio alphabetica, [in:] Patrologiae cursus completus, Series graeca, vol. LXV, ed. J.-P. Migne, Paris 1858, col. 71-442.

Basilius Magnus, Epistulae, [in:] Patrologiae cursus completus, Series graeca, vol. XXXII, ed. J.-P. Migne, Paris 1857, col. 219-1115.

Basilius Magnus, In illud dictum Evangelii secundum Lucam: destruam horrea mea, et majora aeduficabo; iteamquae de avaritia, [in:] Patrologiae cursus completus, Series graeca, vol. XXXI, ed. J.-P. Migne, Paris 1857, col. 261-278.

Cyrillus Scythopolitanus, Vitae Monachorum Palestinensae, [in:] E. Schwartz, Kyrillos von Skythopolis, Leipzig 1939 [= Texte und Untersuchungen zur Geschichte der altchristlichen Literatur, 49.2], p. 1-253.

Gerontius, Vita Melaniae Iunioris. Greek edition: Vie de sainte Mélanie, trans. et ed. D. GorCE, Paris 1962 [= Sources chrétiennes, 90].

Gerontius, Vita Melaniae Iunioris. Latin edition: Gérontius, La Vie Latine de Sainte Mélanie, trans. et ed. P. LAUrenCE, Jerusalem 2002 [= Studium biblicum franciscanum: Collectio minor, 41].

Gregorius Nyssenus, Contra usurarios, [in:] Patrologiae cursus completus, Series graeca, vol. XLVI, ed. J.-P. Migne, Paris 1862, col. 434-453.

Gregorius Nyssenus, Epistulae, ed. P. Maraval, Paris 1990 [= Sources chrétiennes, 363].

Historia monachorum in Aegypto, ed. A.-J. Festugiere, Bruxelles 1971 [= Subsidia hagiographica, 53].

JoAnnes Chrysostomus, Ad populum Antiochenum, [in:] Patrologiae cursus completus, Series graeca, vol. XLIX, ed. J.-P. Migne, Paris 1862, col. 15-222.

Joannes Chrysostomus, In Acta Apostolorum, [in:] Patrologiae cursus completus, Series graeca, vol. LX, ed. J.-P. Migne, Paris 1862, col. 3-384.

Joannes Chrysostomus, In Epistulam ad Ephesios, [in:] Patrologiae cursus completus, Series graeca, vol. LXII, ed. J.-P. Migne, Paris 1862, col. 9-176.

Joannes Chrysostomus, In Epistulam ad Philippenses, [in:] Patrologiae cursus completus, Series graeca, vol. LXII, ed. J.-P. Migne, Paris 1862, col. 177-298.

Joannes Chrysostomus, In Epistulam I ad Corinthios, [in:] Patrologiae cursus completus, Series graeca, vol. LXI, ed. J.-P. Migne, Paris 1862, col. 9-382.

Joannes Chrysostomus, In Epistulam II ad Timotheum, [in:] Patrologiae cursus completus, Series graeca, vol. LXII, ed. J.-P. Migne, Paris 1862, col. 599-662. 
Joannes Chrysostomus, In Johannem, [in:] Patrologiae cursus completus, Series graeca, vol. LIX, ed. J.-P. Migne, Paris 1862, col. 23-482.

Joannes Chrysostomus, In Matthaeum, [in:] Patrologiae cursus completus, Series graeca, vol. LVIILVIII, ed. J.-P. Migne, Paris 1862, col. 13-794.

Joannes Chrysostomus, In paraliticum per tectum demissum, [in:] Patrologiae cursus completus, Series graeca, vol. LI, ed. J.-P. Migne, Paris 1862, col. 47-64.

Joannes Moschus, Pratum spirituale, [in:] Patrologiae cursus completus, Series graeca, vol. LXXXVII.3, ed. J.-P. Migne, Paris 1865, col. 2852-3112.

John Moschos, The Spiritual Meadow, ed. et trans. J. WortLey, Kalamazoo 1992.

Julien, Le Misopogon, [in:] L'Empereur Julien, Ouvres complètes, vol. II, ed. C. Lacombrade, Paris 1964 [= Collection des Universités de France].

Leontius Neapoleos, Vita Joannis Eleemosynarii, [in:] Leontios von Neapolis Leben des hl. Johannes des Barmherzigen, ed. H. Gelzer, Freiburg im Breisgau 1893.

Leontius of Neapolis, Life of John the Almsgiver, [in:] E. Dawes, N.H. Baynes, Three Byzantine Saints. Contemporary Biographies Translated from Greek, Oxford 1948, p. 207-270.

Palladius, Dialogue sur la vie de Jean Chrysostome, vol. I-II, ed. et trans. A.M. Malingrey, P. LeCLERCQ, Paris 1988 [= Sources chrétiennes, 341-342].

Palladius, The Lausiac History, vol. II, ed. et trans. C. Butler, Cambridge 1904.

Procopius, Historia arcana, [in:] Procopius with an English Translation, vol. VI, The Anecdota or Secret History, ed. H.B. Dewing, Cambridge Mass. 1960.

Sozomenus, Kirchengeschichte, ed. J. Bidez, G.C. Hansen, Berlin 1995 [= Die griechischen christlichen Schriftsteller der ersten [drei] Jahrhunderte. Neue Folge, 4].

Théodoret de Cyr, Histoire des moines de Syrie, vol. I-II, ed. et trans. P. CAnivet, A. Leroy-MoLINGHEN, Paris 1977-1979 [= Sources chrétiennes, 234, 468].

Vita Danielis, [in:] Vie et recits de Abbe Daniel de Scêtê, ed. L. Clugnet, "Revue de l'Orient Chrétien" 5, 1900, p. 49-73, 254-271, 370-391.

Vita Olympiadis, ed. et trans. A.-M. Malingrey, Paris 1968 [= Sources chrétiennes, 13 bis].

Vita s. Auxentii, [in:] Patrologiae cursus completus, Series graeca, vol. CXIV, ed. J.-P. Migne, Paris 1864, col. 1377-1436.

\section{Secondary Literature}

Bachmann U., Medizinisches in den Schriften des griechischen Kirchenvater Johannes Chrysostomos [PhD Thesis, Düsseldorf 1984].

Chadwick H., John Moschus and His Friend Sophronius the Sophist, "The Journal of Theological Studies” 25, 1974, p. 41-74, https://doi.org/10.1093/jts/XXV.1.41

Clarysse W., Clothing the House. Furnishing Textiles of the $1^{\text {st }}$ Millennium AD from Egypt and Neighbouring Countries, [in:] Textiles and Architecture in the Graeco-Roman and Byzantine Egypt. Proceedings of the $5^{\text {th }}$ Conference of the Research Group 'Textiles from the Nile Valley', 6.10.20077.10.2007, ed. W. Clarysse, K. Geens, A. De Moor, C. Fluck, Antwerp 2009, p. 38-47.

Dagron G., Naissance d'une capitale. Constantinople et ses institutions de 330 à 451, Paris 1974 [= Bibliothèque byzantine. Études, 7].

Dawes E., Baynes N.H., Three Byzantine Saints. Contemporary Biographies Translated from Greek, Oxford 1948. 
Déroche V., Études sur Léontios de Néapolis, Upsala 1995 [= Studia Byzantina Upsaliensia, 3].

Devos P., Les nombres dans l'Historia monachorum in Aegypto, "Analecta Bollandiana" 92, 1974, p. 97-108, https://doi.org/10.1484/J.ABOL.4.02935

Efthymiadis S., Déroche V., Binggeli A., Aïnalis Z., Greek Hagiography in Late Antiquity (FourthSeventh Centuries), [in:] The Ashgate Research Companion to Byzantine Hagiography, vol. I, Periods and Places, ed. S. Efthymiadis, Farnham-Burlington 2011, p. 35-94.

Fehling D., Die Quellenangaben bei Herodot. Studien zur Erzählkunst Herodots, Berlin-New York 1971 [= Untersuchungen zur antiken Literatur und Geschichte, 9], https://doi.org/10.1515/ 9783110841930

Fuusin B., Palestinian Hagiography (Fourth-Eight Centuries), [in:] The Ashgate Research Companion to Byzantine Hagiography, vol. I, Periods and Places, ed. S. Efthymiadis, Farnham-Burlington 2011, p. 199-226.

Follieri E., Dove e quando mori Giovanni Mosco?, "Rivista di Studi Bizantini e Neoellenici” 25, 1988, p. 3-39.

Frings H.J., Medizin und Arzt bei den griechischen Kirchenvätern bis Chrysostomos, Bonn 1959.

Gonzalez-Blanco A., Economia y sociedad en el Bajo Imperio segun san Juan Crisostomo, Madrid 1980.

Inssen B.L., John Moschos' Spiritual Meadow. Authority and Autonomy at the End of the Antique World, Washington 2013.

Jones A.H.M., Martindale J.R., Morris J., Prosopography of the Later Roman Empire, Cambridge 1980.

Karayannopulos J., Das Finanzwesen des frühbyzantinischen Staates, München 1958.

Mango C.A., A Byzantine Hagiographer at Work: Leontion of Neapolis, [in:] Byzanz und der Westen. Studien zur Kunst des europäischen Mittelalters, ed. I. Hutter, Wien 1984, p. 25-41.

Mehrlein R., Drei, [in:] Reallexikon für Antike und Christentum, vol. IV, ed. T. Klauser, Stuttgart 1959, col. 269-310.

Milewski I., Löhne und Preise bei den Kappadokischen Kirchenvätern und bei Johannes Chrysostomus, "Münstersche Beiträge zur Antiken Handelsgeschichte" 19.1, 2000, p. 48-58.

Milewski I., Lýtron. Okup za odstapienie od oblężenia miasta jako element strategii wojennej Chosroesa I w De bello Persico Prokopiusza z Cezarei, "Studia z Dziejów Średniowiecza" 23, 2019, p. 143-170, https://doi.org/10.26881/sds.2019.23.07

Milewski I., Money in the Apophthegmata Patrum, "Studia Ceranea. Journal of the Waldemar Ceran Research Center for the History and Culture of the Mediterranean Area and South-Eastern Europe" 9, 2019, p. 603-614, https://doi.org/10.18778/2084-140X.09.30

Milewski I., Panis et vinum. Einige Bemerkungen zu den Lebensmittelpreisen und Ernährungsgewohnheiten des spätantiken Menschen bei den griechischen und lateinischen Kirchenväter, [in:] W kręgu antycznych politei. Księga Jubileuszowa ofiarowana Profesorowi Janowi Ilukowi, ed. W. Gajewski, I. Milewski, Gdańsk 2017, p. 262-275.

Milewski I., "Take her, and pay me three gold pieces a day as her hire". Palladius of Helenopolis on Income from Lenocinium, [in:] Byzantina et Slavica. Studies in Honour of Professor Maciej Salamon, ed. S. Turlej, M. Stachura, B.J. KoŁoczek, A. Izdebski, Kraków 2019, p. 273- 281.

Milewski I., Winnica eremity Saby. Uwagi na temat Vita Hilarionis 17, 26-27 autorstwa Hieronima ze Strydonu, "Studia Gdańskie" 42, 2018, p. 79-86.

Morelli F., Gonachia e kaunakai nei papiri con due documenti inediti (P.Vindob. G 1620 e P.Vindob. G 18884) e uno riedito (P.Brook. 25), "The Journal of Juristic Papyrology" 32, 2004, p. 55-81. 
Morelli F., Tessuti e indumenti nel contesto economico tardoantico: I prezzi, "Antiquité tardive" 12, 2004, p. 55-78, https://doi.org/10.1484/J.AT.2.300061

Morrison C., Monnaie et prix à Byzance du V au VII s., [in:] Hommes et richesses dans l'Empire byzantine, IV-VII s., ed. P. Lethielleux, Paris 1989, p. 241-260.

Ostrogorsky G., Löhne und Preise in Byzanz, "Byzantinische Zeitschrift” 32, 1932, p. 293-333, https://doi.org/10.1515/byzs.1932.32.2.293

Pattenden P., The Text of the Pratum Spirituale, "The Journal of Theological Studies" 26, 1975, p. 38-54, https://doi.org/10.1093/jts/XXVI.1.38

Rubincam C., Qualification of Numerals in Thucydides, “American Journal of Ancient History" 4, 1979, p. 77-95, https://doi.org/10.31826/9781463237417-007

Ruffing K., 300, [in:] B. Dunsch, K. Ruffing, Herodots Quellen - die Quellen Herodots, Wiesbaden 2013, p. 201-221.

Tavenner E., Three as a Magic Number in Latin Literature, "Transactions and Proceedings of the American Philological Association” 47, 1916, p. 117-143, https://doi.org/10.2307/282831

Teja R., Organizacion economica y social de Capadocia en el siglo IV, segun los Padres Capadocios, Salamanca 1974.

Whately C., Some Observations on Procopius' Use of Numbers in Descriptions of Combat in Wars Books 1-7, "Phoenix" 69, 2015, p. 394-411, https://doi.org/10.7834/phoenix.69.3-4.0394

\begin{abstract}
This text analyzes three early Byzantine source accounts on clothing prices from the beginning of the $5^{\text {th }}$ to the early $7^{\text {th }}$ centuries in Italy (Rome), Palestine (probably in Jerusalem), and Egypt (Alexandria). The compiled and discussed narrations were compared with other contemporary source reports, which feature analogical figures describing the amount of prices, wages, taxes, and other values or distances. By making a comparative analysis, the author came to the conclusion that these data are recurrent, and, therefore, unreliable. This observation also applies to the clothing prices discussed in the text, which, undoubtedly, should be considered topical.
\end{abstract}

Keywords: early Byzantium, late Roman economy, early Byzantine hagiography, prices in early Byzantium

\title{
Ireneusz Milewski
}

University of Gdańsk

Faculty of History

Institute of History

Department of Ancient History

ul. Wita Stwosza 55

80-952 Gdańsk, Polska/Poland ireneusz.milewski@ug.edu.pl 